\title{
Ab kůrrzungsverzeichnis
}

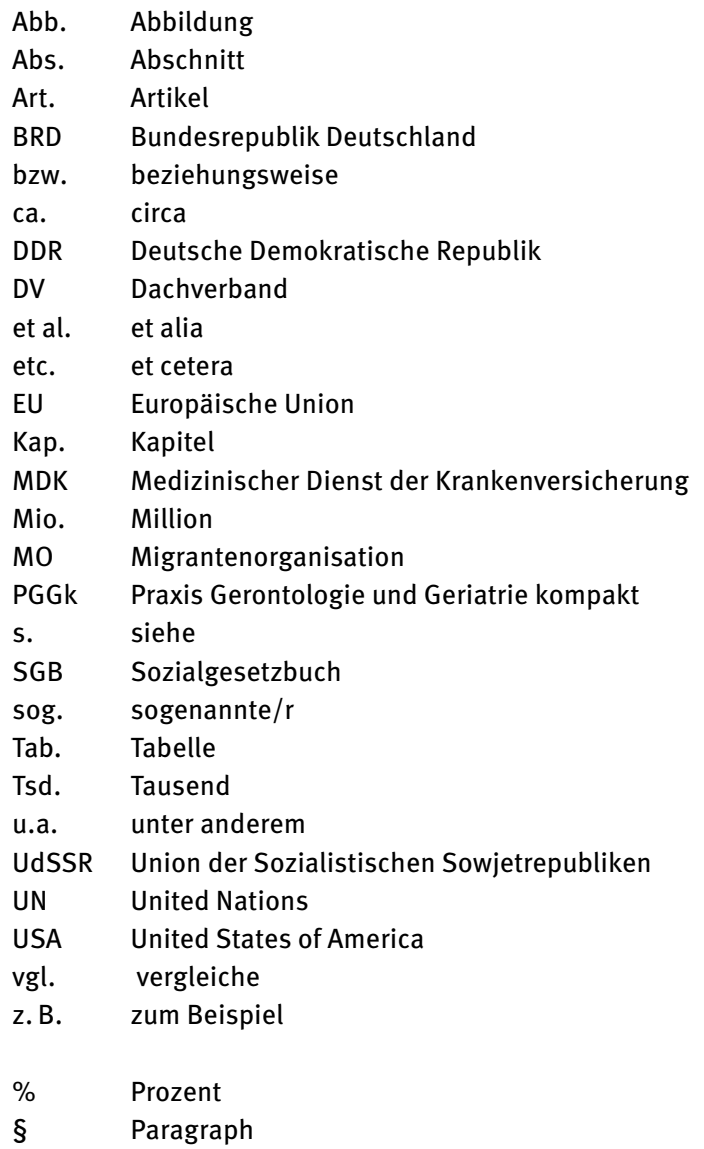


